\title{
Efficiency of Carbonyl Iron in Prevention of Anaemia in Piglets
}

\author{
M. SVOBODA, R. FICEK, B. SYNKOVÁ, J. DRÁBEK \\ University of Veterinary and Pharmaceutical Sciences, Brno, Czech Republic
}

Received July 26, 2006

Accepted February 20, 2007

\begin{abstract}
Svoboda M., R. Ficek, B. Synková, J. Drábek: Efficiency of Carbonyl Iron in Prevention of Anaemia in Piglets. Acta Vet Brno 2007, 76: 179-185.

The aim of this study was to evaluate efficiency of elemental iron preparation in the form of carbonyl iron in prevention of iron deficiency in piglets. The piglets in group $\mathrm{I}(\mathrm{n}=14)$ were given $210 \mathrm{mg}$ of carbonyl iron orally at the age of 3 days. The piglets in group II $(\mathrm{n}=15)$ received $210 \mathrm{mg}$ of carbonyl iron orally on days 3 and 9 . In group III $(\mathrm{n}=14)$ the piglets were injected i.m. with $200 \mathrm{mg} \mathrm{Fe} \mathrm{F}^{3+}$ as iron dextran. Fourteen days after birth, haemoglobin concentration in group I started to decrease and the piglets developed anaemia. In group II, at the age of 28 days, $\mathrm{Hb}$ dropped below $80 \mathrm{~g} / \mathrm{l}$ and the piglets developed anaemia. Under conditions of this trial, the oral administration of carbonyl iron did not prevent development of iron deficiency in piglets.
\end{abstract}

Anaemia, haemoglobin, packed cell volume, neonatal period, iron dextran, oral administration

The iron deficiency is a well known problem in swine production. The piglets are born with limited reserves of iron (ca $50 \mathrm{mg}$ ) ( Venn et al. 1947). Without any preventive administration of iron the piglets develop anaemia within 10 - 14 days after birth (Egeli et al. 1998). The most common approach to prevention is i.m. administration of $200 \mathrm{mg} \mathrm{Fe}^{3+}$ in the form of iron dextran (Dilov and Chakurov 1984), although this method is not always without risks. The cases of acute toxicosis after iron dextran injection were described (Süveges and Glávits 1976; Kolb and Hoffmann 1989). An alternative to this method is oral administration of iron salts. Iron fumarate (Svoboda and Drábek 2002), iron lactate (Kotrbáček 2001; Svoboda et al. 2004) and iron sulphate (Schmitz and Müller 1971) have been used in swine production. Only iron salts with bivalent iron are used, because $\mathrm{Fe}^{2+}$ is up to 16 times better absorbed than $\mathrm{Fe}^{3+}$ (Dietzfelbinger 1987). Another possibility for oral iron administration represents elemental uncharged iron. The elemental iron preparation known as carbonyl iron powder has been developed (S acks and Hou chin 1978). "Carbonyl" does not refer to the composition of the iron particles but rather to the manufacturing process in which the controlled heating of vaporized iron pentacarbonyl leads to deposition of uncharged, elemental iron as submicroscopic crystals that form miscroscopic spheres of less than $5 \mu \mathrm{m}$ in diameter. The preparation is more than $98 \%$ pure ( Sacks and Houchin 1978; Gordeuk et al. 1986). Carbonyl iron has been shown to be absorbed and utilized for haemoglobin synthesis both in experimental animals and in humans (Sacks and Houchin 1978; Gordeuk et al. 1987). Carbonyl iron has been used for iron supplementation after blood transfusions (Gordeuk et al. 1990; Bianco et al. 2002). The carbonyl iron is less toxic compared to iron salts and has the advantage of decreased or absent risk of poisoning if accidentally ingested by children (Gordeuk 1987). To the authors' knowledge, carbonyl iron has not yet been tested for the prevention of iron deficiency in suckling piglets.

\section{Materials and Methods}

Experimental design

A total of 53 piglets were used in the study. The piglets were divided into 4 groups using split litters, i.e. each litter was divided into four different groups. The carbonyl iron preparation (98\% of elemental iron,

Address for correspondence:
MVDr. Martin Svoboda, Ph.D.
University of Veterinary and Pharmaceutical Sciences
Palackého 1-3, 61242 Brno
Czech Republic
Phone: +420 541562433

E-mail: svobodama@vfu.cz

http://www.vfu.cz/acta-vet/actavet.htm 
Superferrin, Favea s.r.o.) was used in our study. One capsule contained $14 \mathrm{mg}$ of carbonyl iron and $200 \mu \mathrm{g}$ of folic acid.

The piglets in group I ( $\mathrm{n}=14$ ) were given $210 \mathrm{mg}$ of carbonyl iron orally ( 15 capsules, $3 \mathrm{mg}$ of folic acid) at the age of 3 days. At the age of 14 days they were treated with iron dextran (i.m., $200 \mathrm{mg} \mathrm{Fe}^{3+}$ ). The piglets in group II $(\mathrm{n}=15)$ received $210 \mathrm{mg}$ of carbonyl iron orally ( 15 capsules, $3 \mathrm{mg}$ of folic acid) on day 3 and 9 . In group III ( $\mathrm{n}=$ 14) the piglets were injected i.m. with $200 \mathrm{mg} \mathrm{Fe}^{3+}$ in the form of iron dextran (Ferridextran 10\%, Spofa a.s., Praha) and were given orally $3 \mathrm{mg}$ of folic acid (Pharam Nord Praha, s.r.o.). The piglets in group IV $(\mathrm{n}=10)$ did not receive any iron treatment until the age of 21 days. At this age they were treated with iron dextran (i.m., $200 \mathrm{mg} \mathrm{Fe}{ }^{3+}$ ).

The creep feed (Maxi creep, Slavkovské krmné směsi a.s., Marefy, iron content $225 \mathrm{mg} / \mathrm{kg} \mathrm{Fe}$ ) was offered to piglets from day 7 to day 35 . The piglets were weaned at the age of 28 days.

Sampling

Blood was collected on days 3, 9, 14, 21, 28 and 35 from vena cava cranialis of the piglets. EDTA (ethylenediaminetetraacetic acid) was used as anticoagulant for the haematological examination. Heparin was used as anticoagulant for determination of iron concentration in blood plasma.

\section{Haematological analysis}

Haematological examination included: haemoglobin concentration $(\mathrm{Hb})$, packed cell volume (PCV), red blood cell count (RBC), mean corpuscular volume (MCV), mean corpuscular haemoglobin $(\mathrm{MCH})$ and mean corpuscular haemoglobin concentration (MCHC). These indices were determined by haematological analyzer Celtac Alfa (Nihon Kohden).

\section{Iron concentration}

Iron concentration in blood plasma $(\mathrm{Fe})$ was determined photometrically, measuring iron complex with ferrozin according to Suw ansaksri et al. (2003) (Iron liquid 917, Roche Diagnostic, Manheim, Germany).

\section{Statistical analyses}

The results were evaluated statistically by Kruskal Wallis ANOVA.

The results are presented as mean values and standard deviation of each index in Figs $1-8$. Values with $* p<0.05$, ${ }^{* *} p<0.01$ express significant differences between iron dextran (group III) and the two carbonyl iron groups (group I, group II).

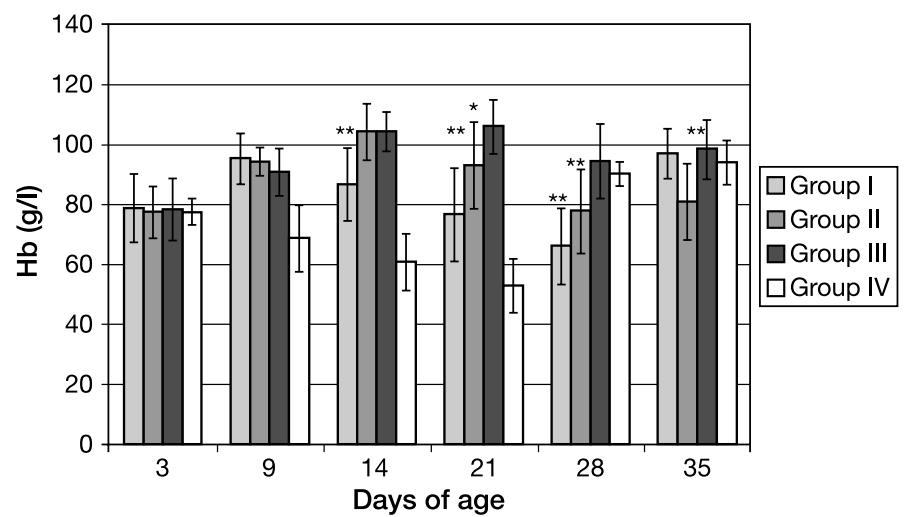

Fig. 1. Haemoglobin concetration

\section{Results}

The administration of $210 \mathrm{mg}$ of carbonyl iron (group I) at the age of 3 days (day 3) resulted in a significant increase of $\mathrm{Hb}, \mathrm{Fe}, \mathrm{PCV}, \mathrm{MCV}$ and $\mathrm{MCH}$ on day 9. Yet, on day 14 the above mentioned indices decreased and were significantly lower compared to iron dextran group $(p<0.01)$. The low values of Fe on day 14 indicate development of subclinical anaemia. The $\mathrm{Hb}$ values on days 21 and 28 were found to be lower than $80 \mathrm{~g} / \mathrm{l}$ (anaemic limit). Therefore the piglets were given i.m. $200 \mathrm{mg} \mathrm{Fe}^{3+}$ as iron dextran on day 28 . The body weight of piglets was significantly lower compared to iron dextran group. 


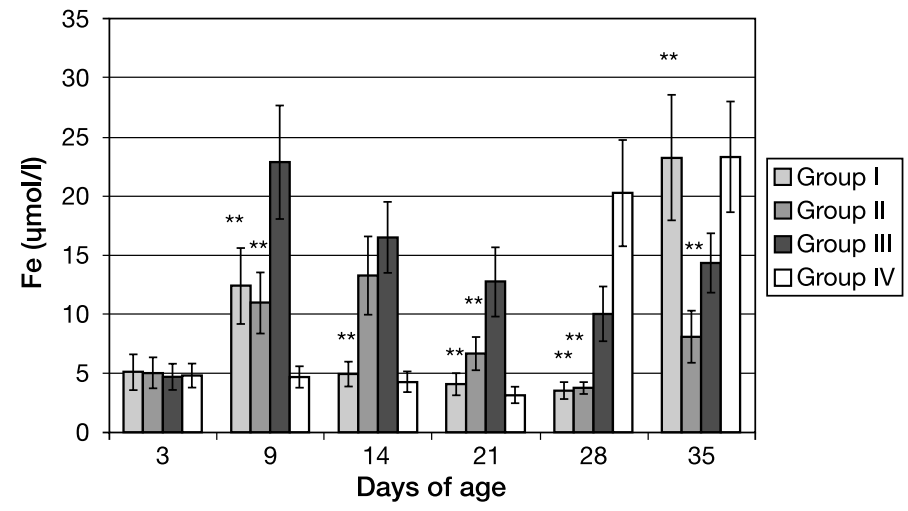

Fig. 2. Iron concentration in blood plasma

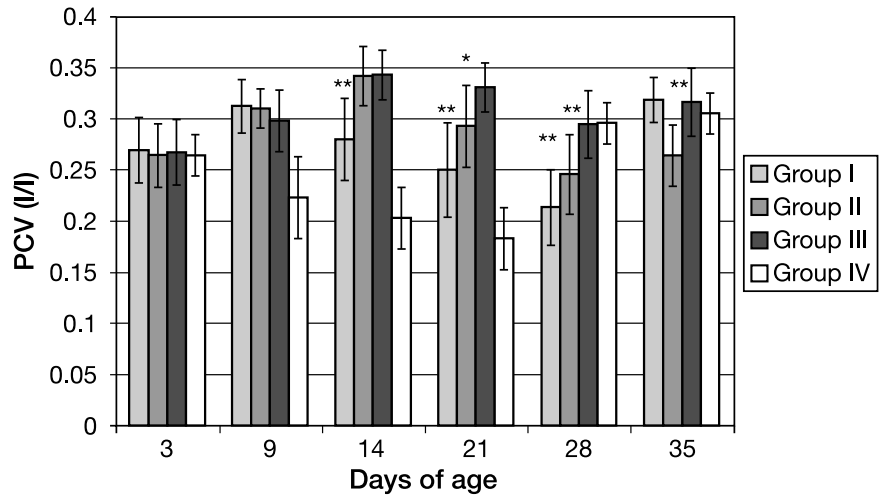

Fig. 3. Packed cell volume

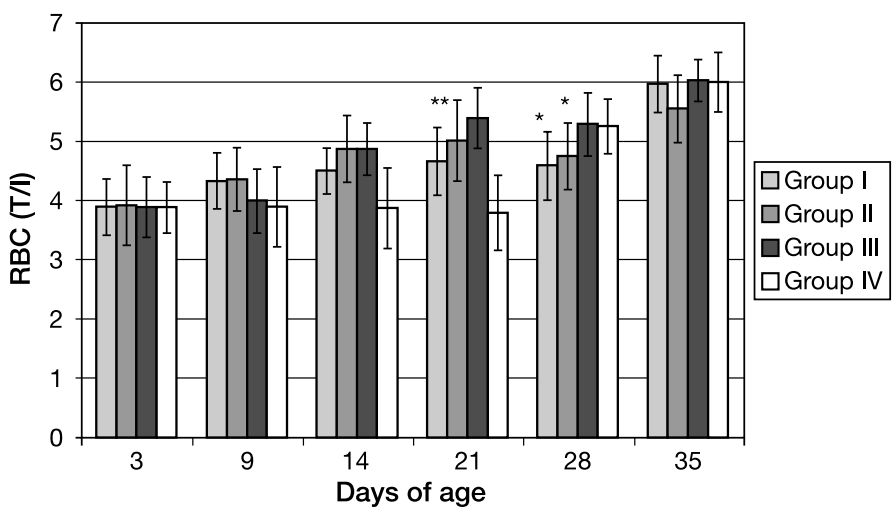

Fig. 4. Red blood cell count 


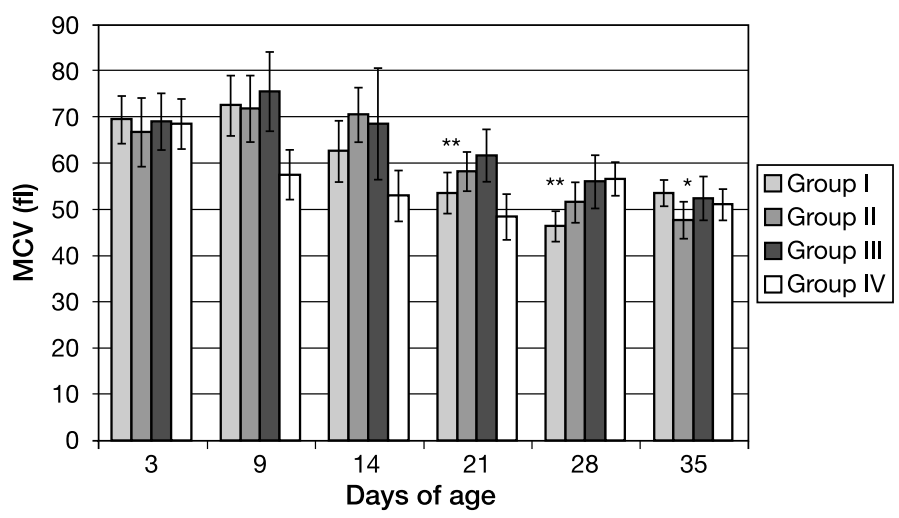

Fig. 5. MCV

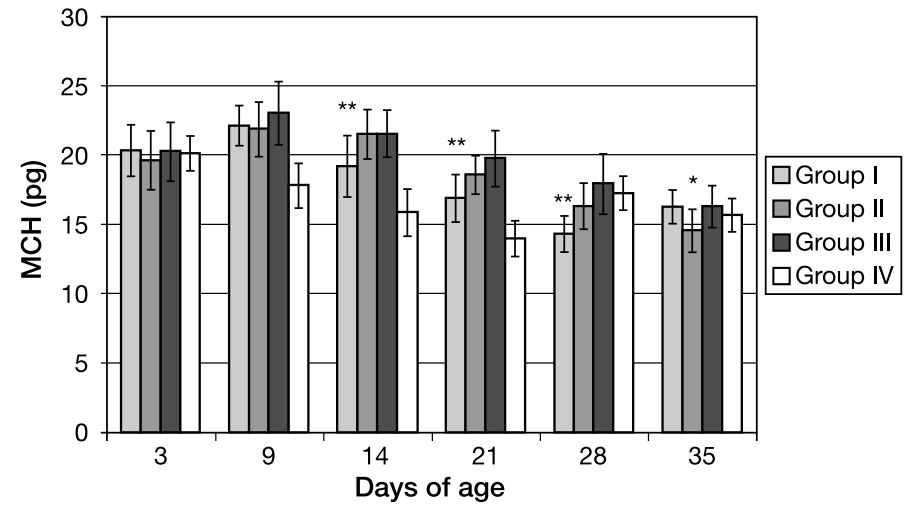

Fig. 6. $\mathrm{MCH}$

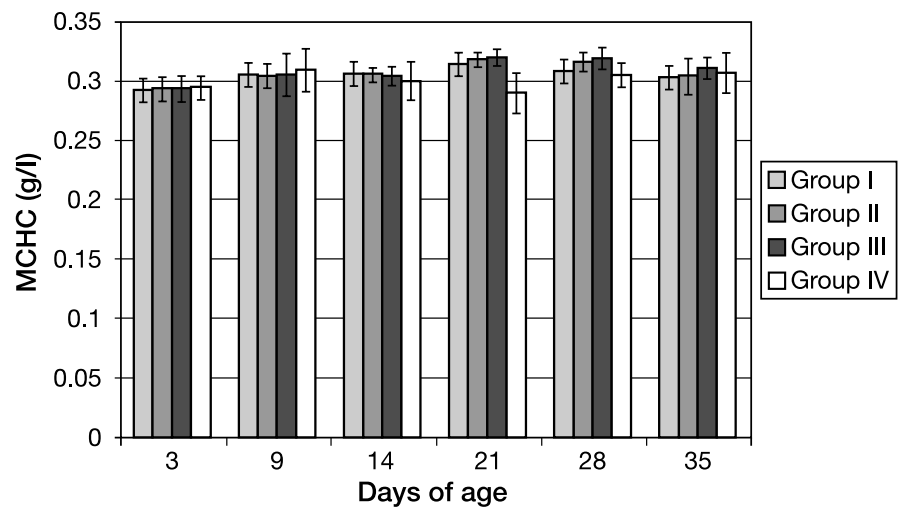

Fig. 7. MCHC 


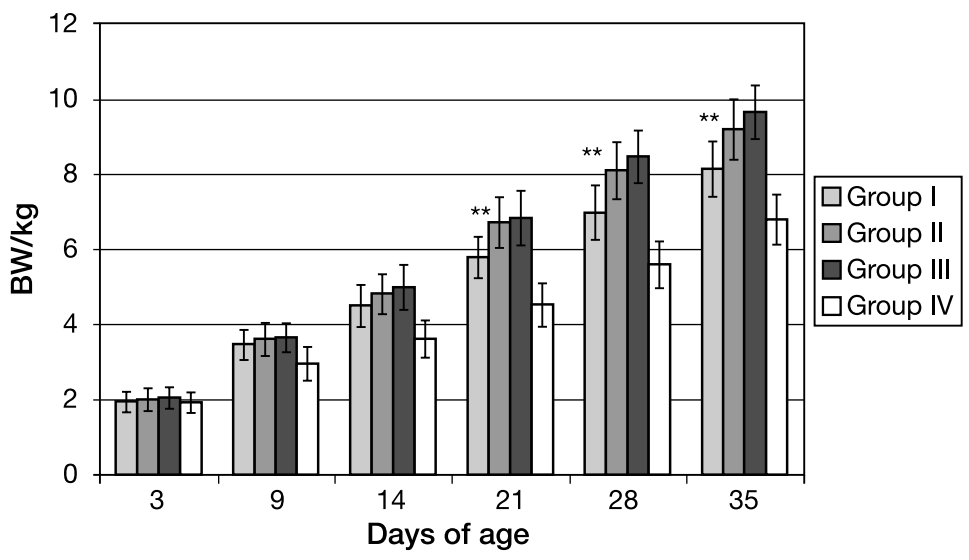

Fig. 8. Body weight

After a double dose of $210 \mathrm{mg}$ of carbonyl iron on days 3 and 9 (group II), the red blood cell indices and $\mathrm{Fe}$ were found to be comparable to those of the iron dextran group until the age of 14 days. From day 14 until the end of the trial Hb, Fe, PCV, MCV and MCH showed decreasing tendency and on day $28 \mathrm{Hb}$, PCV (both, $p<0.01)$, RBC $(p<0.05$ ) and Fe $(p<0.01)$ were significantly lower than in the iron dextran group. On day $28 \mathrm{Hb}$ values were lower than $80 \mathrm{~g} / \mathrm{l}$. No differences in $\mathrm{MCHC}$ were found among the groups during the trial.

The development of red blood cell indices and $\mathrm{Fe}$ in the group of piglets that did not receive any iron until the age of 21 days (group IV) was as expected, and the development of anaemia and decreased body weight of piglets were recorded.

\section{Discussion}

The anaemic limit, i.e. the point when iron deficiency gives clinical symptoms of anaemia, is set by most authors at a haemoglobin concentration below $80 \mathrm{~g} / \mathrm{l}$ (Furugouri 1975; van Kempen 1987). From our results it can be concluded that neither a single nor a double dose of $210 \mathrm{mg}$ of carbonyl iron did prevent development of iron deficiency in piglets. Compared to good efficiency of i.m. administration of $200 \mathrm{mg} \mathrm{Fe}^{3+}$ as iron dextran, it is evident that utilization of carbonyl iron was much lower. This could be explained by specific mechanism of carbonyl iron absorption.

The combination of carbonyl iron and folic acid was used in the study. The folic acid has an important role in erythropoiesis. Erythroblasts require folic acid for proliferation during their differentiation (Koury and Ponka 2004). The same amount of folic acid was also given to piglets that were injected intramuscularly with iron dextran.

The conversion of particulate carbonyl iron to soluble ionized iron by stomach acid is a prerequisite for absorption and is limited by the rate of gastric acid production (Huebers et al. 1986). With ferrous iron salts, all the iron is in a soluble ionized form and is potentially available for absorption. With carbonyl iron, however, only that fraction solubilized by gastric acid is available for absorption. According to S w ain et al. (2003) the bioavailability of carbonyl iron in rats is $64 \%$ of that of ferrous sulphate. Devasthali et al. (1991) found in humans that the bioavailability of carbonyl iron was about $70 \%$ of that of ferrous sulphate. These data show higher bioavailability of iron salts. This is also in agreement with our previous study where we have demonstrated the same efficiency of a double dose of $200 \mathrm{mg}$ $\mathrm{Fe}^{2+}$ in the form of iron fumarate as that of i.m. administration of $200 \mathrm{mg} \mathrm{Fe}^{3+}$ in the form of iron dextran (Svoboda and Drábek 2002). 
In addition, the rate of solubilization is restricted by the rate of gastric acid production (Huebers et al. 1986). Swain et al. (2003) showed that solubility of carbonyl iron depends on gastric $\mathrm{pH}$, i.e. it is less soluble at higher $\mathrm{pH}$. It should be taken into account that the previously cited bioavailabilities of carbonyl iron (Devasthali et al. 1991; Swain et al. 2003) were obtained at gastric $\mathrm{pH}$ below 2 . Because of relatively high $\mathrm{pH}$ of gastric content in suckling piglets, the negative effect of gastric $\mathrm{pH}$ on carbonyl iron utilization could be expected.

It has been documented that gastric mucosa of newborn piglets has a secretory activity of hydrochloric acid production (Cranwell et al. 1976; Black et al. 1981; Sangild et al. 1995). However, this secretory activity has limited capacity in suckling piglets (Cran well et al. 1976). The major contributor to acidification of the stomach content of suckling piglets is lactic acid produced by the fermentation process (Cranwell et al. 1976). Snoeck et al. (2003) documented values of gastric $\mathrm{pH}$ in suckling piglets ranging from 3.0 - 4.1. Similar data were obtained by Cranwell et al. (1976) who reported mean gastric $\mathrm{pH} 4.1 \pm 0.9$ at the age of 2 days and $4.1 \pm 0.5$ at the age of 10 days.

The relatively high gastric $\mathrm{pH}$ in suckling piglets can be explained by several factors. Firstly, the stomach of suckling piglets has a less developed capacity to secrete hydrochloric acid (Cranwell et al. 1976). Secondly, the sow's milk is not strongly stimulating for this secretion, and has a considerable buffering capacity (Cranwell et al. 1976; S noeck et al. 2004). Thirdly, lactic acid production from lactobacilli in the stomach of suckling piglets can partly or completely inhibit acidification by $\mathrm{HCl}$ (Cranwell et al. 1976).

It can be concluded that oral administration of carbonyl iron resulted in a significant haematological response but it did not prevent iron deficiency of piglets under the conditions of our trial. We suggest that more frequent administration would be necessary in order to achieve efficiency comparable to iron dextran; however, this is hardly feasible under practical conditions of pig production.

\section{Prevence nedostatku železa u sajících selat pomocí karbonylového železa}

Cílem studie bylo zjistit, jaká je účinnost karbonylového železa pro prevenci nedostatku železa u selat. Selatům ve skupině I $(\mathrm{n}=14)$ bylo aplikováno perorálně $210 \mathrm{mg}$ karbonylového železa ve věku 3 dnů. Selatům ve skupině II $(n=15)$ bylo podáno perorálně 210 mg karbonylového železa ve věku 3 a 9 dnů. Selatům ve skupině III $(n=14)$ bylo aplikováno $200 \mathrm{mg} \mathrm{Fe}^{3+}$ ve formě dextranu železa. Čtrnáct dní po narození začala koncentrace hemoglobinu ve skupině I klesat a u selat se vyvinula anémie. Ve skupině II klesla koncentrace hemoglobinu ve věku 28 dnů pod $80 \mathrm{~g} / \mathrm{l}$ a u selat se vyvinula anémie. Za podmínek této studie nezabránila perorální aplikace karbonylového železa vzniku anémie u selat.

\section{Acknowledgement}

The study was supported by the project MSM 6215712403.

\section{References}

BIANCO C, BRITTENHAM GM, GILCHER RO, GOREDUK VR, KUSHNER MS, CHAMBERS L, COUNTS RB, AYLESWORTH C, NEMO G, ALVING B 2002: Maintaining iron balance in women blood donors of childbearing age: summary of a workshop. Transfusion 42: 798-805

BLACK JA, FORTE TM, FORTE JG 1981: Inhibition of $\mathrm{HCl}$ secretion and the effects on ultrastructure and electrical resistance in isolated piglet gastric mucosa. Gastroenterology 81: 509-519

CRANWELL PD, NOAKES DE, HILL KJ 1976: Gastric secretion and fermentation in the suckling pig. Br J Nutr 36: $71-86$

DEVASTHALI SD, GORDEUK VR, BRITTENHAM GM, BRAVO JR, HUGHES MA, KEATING LJ 1991: Bioavailability of carbonyl iron: a randomized, double-blind study. Eur J Haematol 46: 272-278

DIETZFELBINGER H 1987: Bioavailability of bi- and trivalent oral iron preparations. Investigations of iron absorption by postabsorption serum iron concentrations curves. Arzneimittelforschung 37: 107-112 
DILOV P, CHAKUROV R 1984: Incidence and drug prevention of anemia in pigs in commercial swine breeding. Vet Med Nauki 21: 111-119

EGELI AK, FRAMSTAD T, MORBERG H 1998: Clinical biochemistry, haematology and body weight in piglets. Acta Vet Scand 39: 381- 393

FURUGOURI K 1975: Characteristic aspects of iron metabolism in piglets. Jap Agric Res Quart 9: p. 171

GORDEUK VR, BRITTENHAM GM, BRAVO J, HUGHES MA, KRATING LJ 1990: Prevention of iron deficiency with carbonyl iron in female blood donors. Transfusion 30: 239-245

GORDEUK VR, BRITTENHAM GM, HUGHES M, KRATINY LJ, APPLT JJ 1987: High-dose carbonyl iron for iron deficiency anemia: a randomized double-blind trial. Am J Clin Nutr 46: 1029-1034

GORDEUK VR, BRITTENHAM GM, MCLAREN CE, HUGHES MA, KRATINY LJ 1986: Carbonyl iron for iron deficiency anemia. Blood 67: 745- 752

HUEBERS HA, BRITTENHAM GM, CSIBA E, FINCH CA 1986: Absorption of carbonyl iron. J Lab Clin Med 12: $473-478$

KOLB E, HOFFMANN U 1989: Zur Frage der zweckmässigen Form der Anwendung von Fe-dextran, seiner Verwertung sowie des Mechanismus einer möglichen Schädigung der Ferkel. Mh Vet Med 44: 497-501

KOTRBÁČEK V 2001: Effects of different formulae for oral and parenteral administration of iron on somatic growth and selected haematological indexes in piglets. Czech J Anim Sci 46 : 49-54

KOURY MJ, PONKA P. 2004: New insights into erythropoiesis: the roles of folate, vitamin $\mathrm{B}_{12}$, and iron. Ann Rev Nutr 24: 105- 131

SACKS PV, HOUCHIN DN 1978: Comparative bioavailability of elemental iron powders for repair of iron deficiency anemia in rats: Studies of efficacy and toxicity of carbonyl iron. Am J Clin Nutr 31: 566-571

SANGILD PT, HILSTED L, NEXO E, FOWDEN AL, SILVER M 1995: Vaginal birth versus elective caesarean section: effects on gastric function in the neonate. Exp Physiol 80: 147-157

SCHMITZ H, MÜLLER A 1971: Vergleichende Untersuchung über die therapeutische Wirkung oral applizierter Eisen (II)- bzw. Eisen (III)-Antianämica. Arzneim Forsch 21: 509-515

SNOECK V, COX E, VERDONCK F, JOENSU JJ, GODDEERIS M 2004: Influence of porcine intestinal pH and gastric digestion on antigenicity of F4 fimbriae for oral immunisation. Vet Microbiol 98: 45-53

SUWANSAKSRI J, SOOKARUN S, WIWANITKIT V, BOONCHALERMVICHIAN C, NUCHPRAYOON I. 2003: Comparative study on serum iron determination by different methods. Lab Hematol 9: 234-236

SÜVEGES T, GLÁVITS R 1976: Piglet losses due to parenteral application of iron-dextran preparations. Acta Vet Hung 26: 257- 262

SVOBODA M, DRÁBEK J 2002: Effect of oral administration of $\mathrm{Fe}^{2+}$ - fumarate on erythrocyte profile and growth rate of suckling piglets. Acta Vet Brno 71: 217-222

SVOBODA M, BOUDA J, DRÁBEK J, DOUBEK J 2004: Effect of per os iron lactate supplement on development of haematological profile of piglets in the early postnatal period. Acta Vet Brno 73: 431-436

SWAIN JH, NEWMAN SM, HUNT JR 2003: Bioavailability of elemental iron powders to rats is less than bakerygrade ferrous sulfate and predicted by iron solubility and particle surface area. J Nutr 133: 3546-3552.

VAN KEMPEN GJM 1987: Avoid iron deficiency in piglets. Pigs 3: 10-11

VENN JAJ, MCCANCE RA, WIDDOWSON EM 1947: Iron metabolism in piglet anemia. J Comp Pathol 57: 314-325 